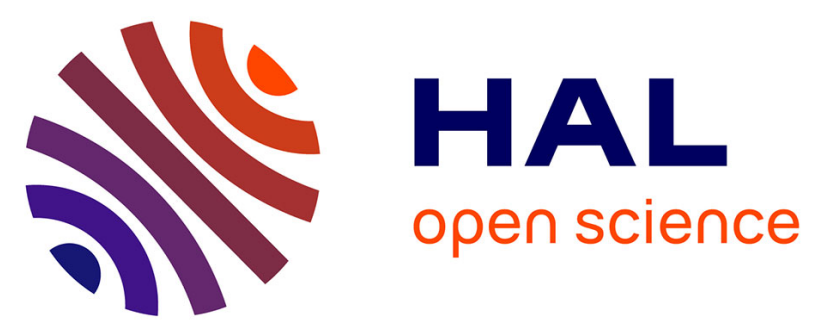

\title{
A solvent-free, catalyst-free formal [3+3] cycloaddition dearomatization strategy: towards new fluorophores for biomolecules labelling
}

Liang Chang, Nathalie Fischer-Durand, Geoffrey Gontard, Benoît Bertrand, Serge Thorimbert, Luc Dechoux

\section{To cite this version:}

Liang Chang, Nathalie Fischer-Durand, Geoffrey Gontard, Benoît Bertrand, Serge Thorimbert, et al.. A solvent-free, catalyst-free formal [3+3] cycloaddition dearomatization strategy: towards new fluorophores for biomolecules labelling. ChemSusChem, 2021, 14 (8), pp.1821-1824. 10.1002/cssc.202100301 . hal-03168419

\section{HAL Id: hal-03168419 https://hal.science/hal-03168419}

Submitted on 13 Mar 2021

HAL is a multi-disciplinary open access archive for the deposit and dissemination of scientific research documents, whether they are published or not. The documents may come from teaching and research institutions in France or abroad, or from public or private research centers.
L'archive ouverte pluridisciplinaire HAL, est destinée au dépôt et à la diffusion de documents scientifiques de niveau recherche, publiés ou non, émanant des établissements d'enseignement et de recherche français ou étrangers, des laboratoires publics ou privés. 


\title{
A solvent-free, catalyst-free formal [3+3] cycloaddition dearomatization strategy: towards new fluorophores for biomolecules labelling
}

\author{
Liang Chang, Nathalie Fischer-Durand, Geoffrey Gontard, Benoît Bertrand, \\ Serge Thorimbert* and Luc Dechoux*
}

\begin{abstract}
L. Chang, Dr. N. Fischer-Durand, G. Gontard, Dr. B. Bertrand, Prof. Dr. S. Thorimbert, and Dr. L. Dechoux
Sorbonne Université, CNRS, Institut Parisien de Chimie Moleculaire, IPCM, F-75005 Paris, France.

Dr. L. Chang present address : Department of Medicinal Chemistry, Nanjing University of Chinese Medicine, Nanjing 210023, China

E-mail: luc.dechoux@sorbonne-universite.fr; serge.thorimbert@sorbonne-universite.fr
\end{abstract}

\begin{abstract}
A general, sustainable dearomatization reaction for nitrogen-containing heterocycles was developed. Under solvent free conditions and without catalyst, the biorenewable methyl coumalate (MC) reacts as an efficient C3 partner to convert nine types of basic aromatic rings into their pyrido[1,2-a] fused derivatives in good to excellent yields. The fluorescence properties of some of the products were harnessed to conjugate fluorescent tags to BSA and immunoglobulin G.
\end{abstract}

The extensive use of synthetic fluorophores in biological imaging ${ }^{[1]}$ makes them prime candidates in organic synthesis projects. This photophysical property is interesting for the labelling of biomolecules such as amino acids, peptides, proteins, and DNA. In general, fluorescent organic skeletons contain polycyclic conjugated systems with mobile electrons, see for instance BODIPYs, rhodamines, 1,8-naphtalamides, fluoresceins and oxadiazoles. ${ }^{[2]}$ These electronic characteristics may sometimes allow, after interaction with the target, a change in the fluorescence properties. In this article we present the synthesis of such platforms with such electronics features, based on the dearomatization of pyridine or other nitrogen-based aromatics.

To access conjugated non-aromatic polycyclic scaffolds, dearomatization reactions have been continuously regarded as an attractive strategy. ${ }^{[3]}$ However, the structural complexity of aza-aromatic units renders general methods for dearomatization very challenging. Generally, the construction of such polycyclic compounds relies on the direct addition of nucleophile to preactivated pyridinium intermediates, known as the Reissert reaction. ${ }^{[4]}$ Another strategy relies on the internal electrophile-triggered $\mathrm{C}-\mathrm{N}$ bond forming dearomatization reactions. For instance, You and coworkers reported Ir-catalyzed intramolecular asymmetric allylic dearomatization reaction of pyridines and pyrazines, ${ }^{[5]}$ quinolines and (iso)-quinolines, ${ }^{[6]}$ benzoxazoles, benzothiazoles and benzimidazoles. ${ }^{[7]}$ Unsworth's group reported a high-yielding silver(I)- or copper(II)-catalyzed dearomatizing intramolecular cyclization strategy, which allows the conversion of simple aromatic compounds containing ynone substituents, including indole, anisole, pyrrole and benzofuran derivatives, into functionalized quinolizinone scaffolds. ${ }^{[8]}$ In these methods, allylic and propargylic substitutions are mainly achieved via N-nucleophilic aromatics with C-electrophiles. However, this method requires not only the pre-synthesis of electrophiles or their precursors, but also the use of transition metals as catalyst. In the recent years, most of the new dearomatization reactions have consisted in cycloaddition $(\mathrm{CA})$ reactions or formal CA. This includes $[2+2]-,{ }^{[9]}[3+2]-,{ }^{[10]}$ $[3+3]-,{ }^{[11]}[4+2]-,,^{[12]}[5+1]-,{ }^{[13]}[4+3]-C A .{ }^{[14]}$ In most of the cases theses $C A$ reactions concern indole derivatives as substrates.

We have shown that methyl coumalate $(\mathbf{M C})$ reacted as an equivalent of enal with 1,3-dicarbonyl derivatives in formal [3+3] CA giving access to the efficient synthesis of dihydropyrans. The transformation starts by a formal Knoevenagel reaction, which implies a cascade $-1,6$-addition on MC $-6 \pi$-electrocyclic opening $-1,5$-proton shift, leading to the intermediate 1-oxatriene. The final $6 \pi$-electrocyclization gives the dihydropyrans (Scheme 1a). ${ }^{[15]}$ Additional advantage of using MC as a substrate lies in its biorenewable nature, which allows the reaction to run in an environmental-friendly manner. In the context of CA, pyridines have 
been scarcely used, and especially for [3+3] reactions. ${ }^{[11]}$ We postulated that pyridylacetates would react with $\mathbf{M C}$ as for the 1,3dicarbonyl derivatives to form an intermediate 1 -azatriene which would undergo a $6 \pi$-electrocyclization leading to the formation of quinolizine scaffolds (Scheme 1b). Herein we describe a general, sustainable dearomative strategy using the bio-based MC for the conversion of nitrogen-based aromatic rings into their pyrido[1,2-a] fused derivatives.

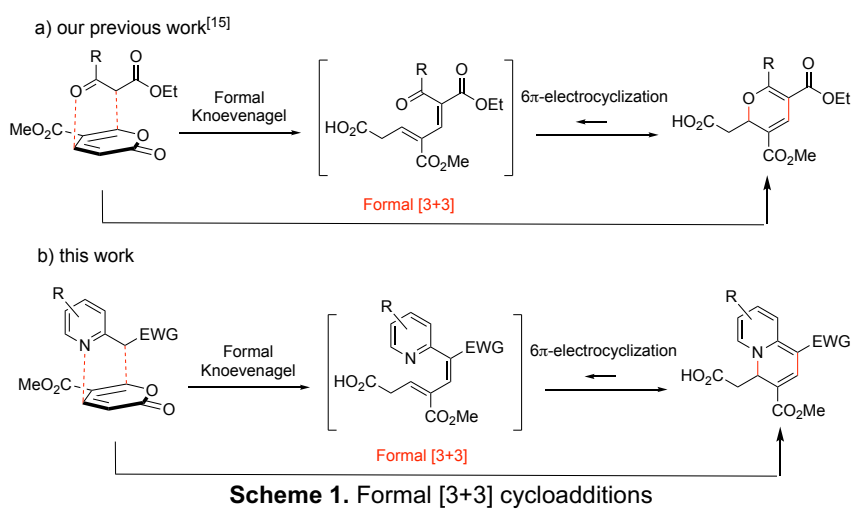

The self-catalyzed imine-enamine tautomerism in pyridyl acetate ${ }^{[16]}$ would generate the nucleophilic enamine required for the reaction to begin. Thus, the reaction could be realized in solvent-free and catalyst-free conditions. These mild reaction conditions were successfully applied to a wide range of different aza-aromatic substrates. To begin with, six-membered aza-aromatics, such as pyridine and pyrazine, afforded the corresponding quinolizine (D-2a) and pyro-pyrazine (D-2b) products in high yield (89\% quant) (Scheme 2). Benzene and pyridine-fused six-membered aza-aromatics, such as quinoline, quinoxaline and naphthyridine, also underwent such reaction with the dearomative products (D-2c, D-2d, D-2e) obtained in $81-87 \%$ yield.

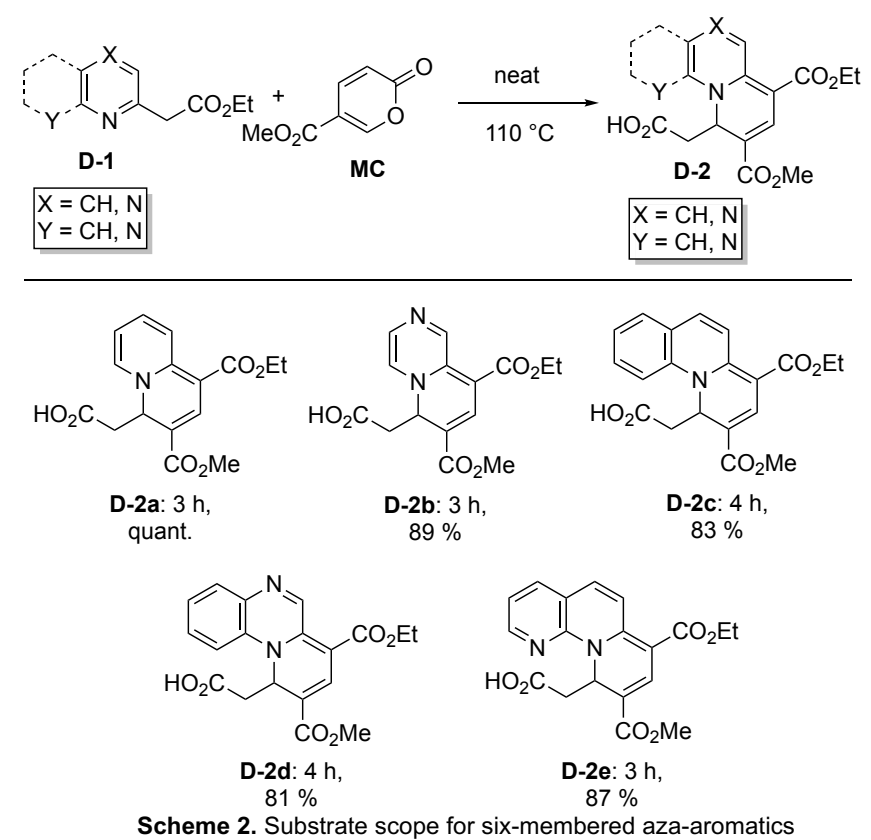


Moreover, five-membered aza-heterocycles also proved to be suitable substrates for this mild dearomatization reaction (Scheme 3). Thiazole, benzoxazole, benzothiazole and unprotected benzoimidazole were all well tolerated, providing their corresponding bi- and tri-cyclic products (D-2f-D-2i) in good to excellent yields. Crystals suitable for X-Ray diffraction were obtained for tricyclic product $\mathbf{D}-\mathbf{2 i}$.
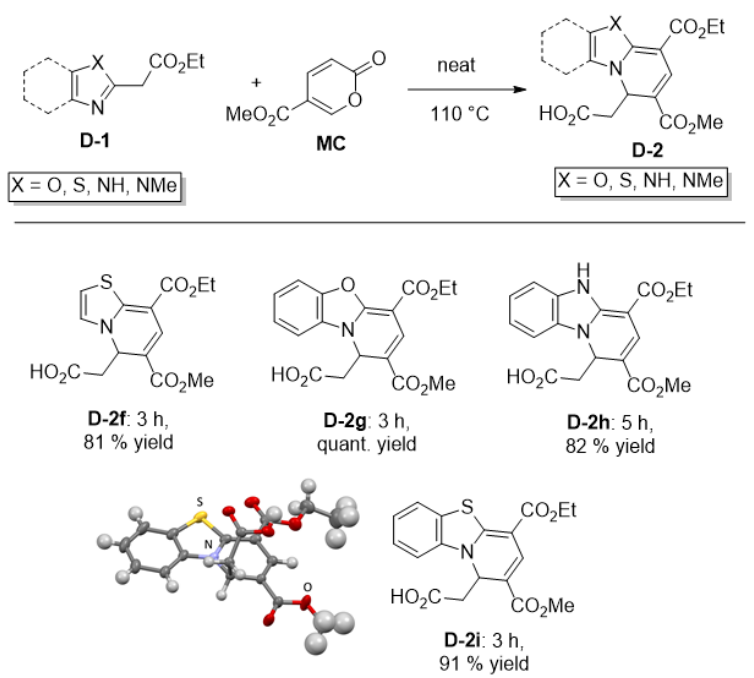

Scheme 3. Substrate scope for five-membered aza-aromatics

Substituted pyridines are also suitable feedstocks for this reaction, leading to corresponding quinolizine products in good to excellent yields (Scheme 4).
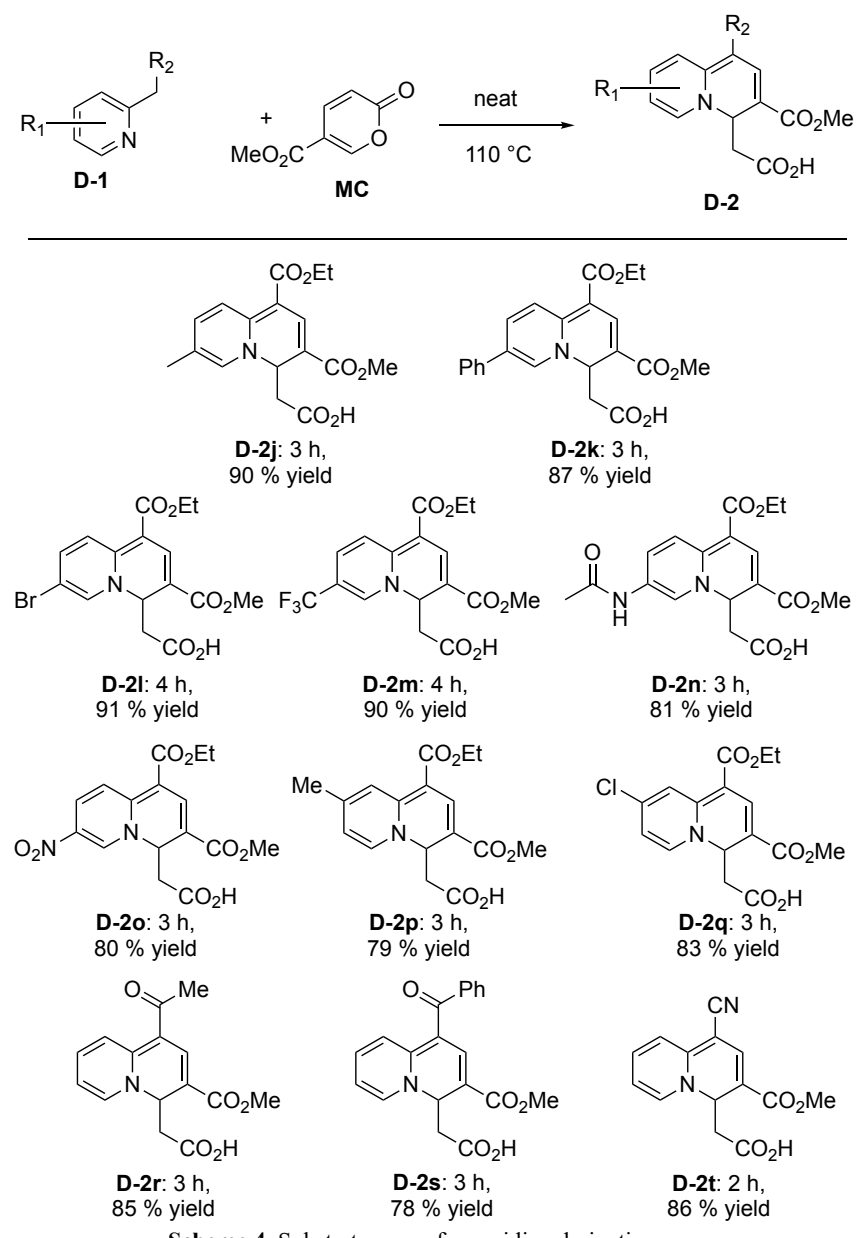

Scheme 4. Substrate scope for pyridine derivatives. 
The dearomatization protocol was insensitive to the presence of electron-donor or electron-withdrawing groups at 5- position on the pyridine ring (D-2j- $\mathbf{D}-\mathbf{2} \mathbf{0})$. Methyl and chloride group at 4- position afford $\mathbf{D}-\mathbf{2} \mathbf{p}$, and $\mathbf{D}-\mathbf{2 q}$ in good yields. Other activated 2-methylpyridine bearing electron-withdrawing group such as ketone or cyanide (-COMe, $-\mathrm{COPh}$ and -CN) were also compatible with this reaction, thus forming another type of substituted products (D-2r-D-2t) in good to excellent yield.

The plausible mechanism for this reaction is illustrated in Scheme 5. The nucleophilic enol D1-a' coming from the tautomeric equilibrium of pyridyl ester $\mathbf{D}-1 \mathbf{a}$ undergoes a 1,6 addition on $\mathbf{M C}{ }^{[17]}$ The resulting intermediate $\mathbf{A}$ could run a $6 \pi$ electrocyclic ring-opening to give $\mathbf{B},{ }^{[18]}$ followed by a 1,5-proton transfer, opening access to 1 -azatriene $\mathbf{C}$. We could not rule out a bimolecular elimination - protonation from $\mathbf{A}$ to $\mathbf{C}$ but the cascade via $\mathrm{B}$ is privileged based on the previous results we observed with Grignard reagents as nucleophiles. ${ }^{[17 a, 18 a]}$ This transformation from starting materials $\mathbf{D}-\mathbf{1}$ to 1 -azatriene $\mathbf{C}$ corresponds to a formal Knoevenagel reaction. A final 6- $\pi$ electrocyclization furnishes the quinolizine D-2a. The presence of two EWG groups at C3 and C5 of the 1-azahexatriene accelerates and favors the $6 \pi$ electrocyclic process. ${ }^{[19]}$

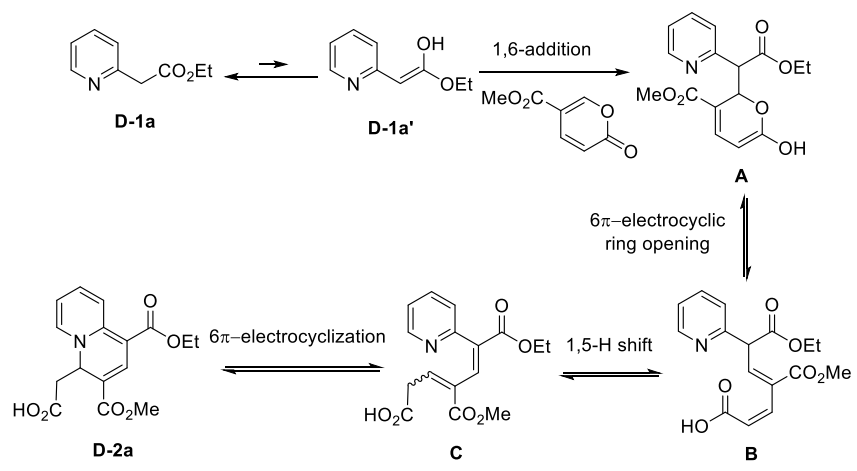

Scheme 5: Plausible mechanism

In addition to be readily performed, this dearomatization reaction, also generates novel structures with potential applications in biological endeavors. The prepared molecules present a carboxylic acid function ready for the grafting onto biomolecules. Thus, the dearomatized products presenting this carboxylic acid moiety were then explored for their emission properties (table S1). It appears that while all 6-membered dearomatized products were poorly to non-emissive, 5-membered dearomatized products (D2$\mathrm{f}-\mathrm{i})$ presented interesting emission properties in the blue region $(441-479 \mathrm{~nm})$ with a shift of the emission wavelength depending on the second heteroatom present in the 5-membered cycle. Among the acquired products, D-2i showed the highest quantum yield (table S1), affording a potential fluorescent marker for the labelling of various biomolecules including proteins, DNA etc. ${ }^{[2]}$

As a model protein, we chose bovine serum albumin (BSA) that has 35 accessible amine functions from lysine residues for potential conjugation. D-2i was first activated into its $\mathrm{N}$-succinimidyl ester and added to a solution of BSA in sodium phosphate buffer $\mathrm{pH} 7.8$ (Figure S1). After reaction, the conjugate was purified by extensive dialysis and ultrafiltration. The average number of fluorescent probe D-2i conjugated per BSA was evaluated by UV-Vis spectroscopy by measuring the concentrations of BSA and D-2i using calibration curves established at their maximal absorbance wavelengths $\left(\lambda_{\max }\right)$ ( 280 and $420 \mathrm{~nm}$ respectively). The conjugation ratio was estimated to be 9 starting with 30 eq. of D-2i per BSA. The covalent nature of the linkage between the protein and D-2i was evidenced by performing an assay without activation of the acid with TSTU. After purification, we detected neither absorbance at $420 \mathrm{~nm}$ nor fluorescence emission at $\lambda_{\mathrm{ex}}=420 \mathrm{~nm}$ (figure $\mathrm{S} 1$, black line) showing that there are no nonspecific interactions. Conjugate BSA-(D-2i)g showed strong fluorescence emission at $490 \mathrm{~nm}$ upon excitation at $420 \mathrm{~nm}$ in PBS pH 7.4 whereas excitation of BSA alone at $420 \mathrm{~nm}$ did not result in any fluorescence emission (Figure S1).

However, to ensure high selectivity and site-specificity, it has become appealing to design bio-conjugation reactions based on functional groups not naturally occurring in biomacromolecules. ${ }^{[21]}$ Among these reactions, the coupling between an acylhydrazine and an aldehyde to form an acyl-hydrazone bond has been frequently used, especially for the site-selective labelling of glycoproteins. As a model of glycoprotein, we chose an immunoglobulin $\mathrm{G}(\mathrm{IgG})$. This choice was motivated by the relevance of fluorophore-antibody conjugates in the field of immunoassays. ${ }^{[22]}$ For this purpose, the acid group of D-2i was activated into its $N$ succinimidyl ester and converted to the protected acyl-hydrazine D-2i-1 upon reaction with $t$-Bu-carbazate. Cleavage of the Boc 
group by $\mathrm{HCl}$ in ether/chloroform led to the acyl hydrazine hydrochloride D-2i-2 (Figure 1a).

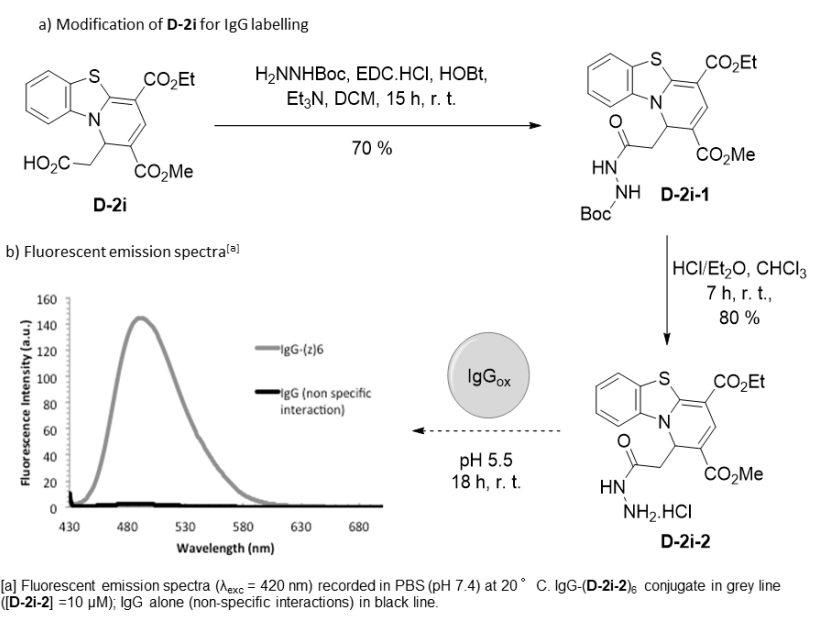

Figure 1. D-2i and derivatives in fluorescent lgG labelling.

Site-selective labelling of IgG was then performed in two steps. First, the carbohydrate moieties located on the Fc region of IgG were oxidized with sodium periodate in acetate buffer $(\mathrm{pH} 4.0)$ in order to generate aldehyde groups. ${ }^{[23]}$ Subsequent reaction with a large excess of acyl hydrazine D-2i-2 (20 eq.) in acetate buffer $\mathrm{pH} 5.5$ for $18 \mathrm{~h}$ at $25^{\circ} \mathrm{C}$ afforded acyl hydrazone bonds that were reduced with $\mathrm{NaBH}_{3} \mathrm{CN}$ to form more stable acyl hydrazine bonds. The acidic conditions used for the oxidation step and the formation of the acyl hydrazone bonds ensured that aldehyde groups reacted only with acyl hydrazine groups and not with amine groups, thus avoiding protein homo-coupling side-reactions. After dialysis and ultrafiltration in order to remove unbound D-2i-2, the average number of fluorescent molecules conjugated per IgG was again evaluated by UV-Vis spectroscopy by measuring the concentrations of D-2i-2 and IgG using calibration curves established at 280 and $420 \mathrm{~nm}$. This conjugation rate was estimated to be 6 , which is consistent with the average number of labelling sites expected to be generated given the chosen oxidation conditions (10 $\left.\mathrm{mM} \mathrm{NaIO}_{4}, \mathrm{pH} 4,0,1 \mathrm{~h}\right) \cdot{ }^{[21]}$ Again, nonspecific interactions were not observed when incubating IgG and $\mathbf{D}-\mathbf{2} \mathbf{i}-\mathbf{2}$ without the oxidation step (i.e. no absorbance at $420 \mathrm{~nm}$ and no fluorescence detected after dialysis: figure 1c, black line: IgG recovered). The fluorescence emission spectrum of IgG-( D-2i-2)6 conjugate was recorded in PBS pH 7.4 upon excitation at $420 \mathrm{~nm}$ and showed strong fluorescence emission at $490 \mathrm{~nm}$ whereas excitation of $\mathrm{IgG}$ alone at $420 \mathrm{~nm}$ did not result in any fluorescence emission (Figure 1).

In summary, we outlined a novel formal [3+3] cycloaddition dearomatization reaction, that consists in a tandem formal Knoevenagel-6 $\pi$-electrocyclization with an unprecedented pyrido[1,2- $\alpha$ ] fused heterocyclic large scope. This reaction can tolerate eleven types of aza-aromatics. This protocol not only employs a biorenewable diene precursor as feedstock without the need of solvent nor catalyst, but also builds the $\mathrm{C}-\mathrm{C}$ and $\mathrm{C}-\mathrm{N}$ bond in one pot, meeting the requirement of green chemistry in both environmental-friendly and step-economical aspects. Furthermore, the products possess novel structures which may serve as new fluorescent dyes, providing promising probes for protein labelling and relevant biological assays.

\section{Acknowledgements}

We thank the Sorbonne Université and CNRS for funding. L.C acknowledges the China Scholarship Council (CSC) for PhD scholarship.

Keywords: dearomatization $\bullet$ nitrogen heterocycles $\bullet$ Michael addition $\bullet$ methyl coumalate $\bullet$ fluorescent probe 
[1] For selected reviews a) S. Yao, S. Wetzel, K. D. Belfield, Eur. J. Org. Chem. 2012, 3199-3217; b) S.-W. Yun, N.-Y. Kang, S.-J Park, H.-H. Ha, Y. K. Kim, J.-S. Lee, Y.-T. Chang, Acc. Chem. Res. 2014, 47, 1277-1286; c) X. Li, X. Gao, W. Shi, H. Ma, Chem. Rev. 2014, 114, 590-659; d) O.S. Wolfbeis Chem. Soc. Rev. 2015, 44, 4743-4768.

[2] For selected reviews a) N. Boens, V. Leen, W. Dehaen, Chem. Soc. Rev. 2012, 41, 1130-1172; b) T. Kowada, H. Maeda, K. Kikuchi, Chem. Soc. Rev. 2015, 44, 4953-4972; c) P. Kaur, K. Singh, J. Mater. Chem. C 2019, 7, 11361-11405.

[3] a) S. P. Roche and J. A. Porco, Angew. Chem. 2011, 123, 4154-4179; Angew. Chem. Int. Ed. 2011, 50, 4068-4093; b) C.-X. Zhuo, C. Zheng, S.-L. You, Acc. Chem. Res. 2014, 47, 2558-2573; c) C. Zheng, S.-L. You, Chem. 2016, 1, 830-857; d) S. Park, S. Chang, Angew. Chem. 2017, 129, 78287847; Angew. Chem. Int. Ed. 2017, 56, 7720-7738; e) H. Liu, M. Khononov, M. S. Eisen, ACS Catal. 2018, 8, 3673-3677; f) M. W. Gribble, S. Guo, S. L. Buchwald, J. Am. Chem. Soc. 2018, 140, 5057-5060.

[4] a) A. Reissert, Berichten der deutschen chemischen gesellschaft, 1905, 38, 1603-1614; For a review b) M. Ahamed, M. H. Todd, Eur. J. Org. Chem. 2010, 5935-5942.

[5] Z.-P. Yang, Q.-F. Wu, S.-L. You, Angew. Chem. 2014, 126, 7106-7109; Angew. Chem. Int. Ed. 2014, 53, 6986-6989.

[6] Z.-P. Yang, Q.-F. Wu, W. Shao, S.-L. You, J. Am. Chem. Soc. 2015, 137, 15899-15906.

[7] Z.-P. Yang, C. Zheng, L. Huang, C. Qian, S.-L. You, Angew. Chem. 2017, 129, 1552-1556; Angew. Chem. Int. Ed. 2017, 56, 1530-1534

[8] M. J. James, N. D. Grant, P. O’Brien, R. J. K. Taylor, W. P. Unsworth, Org. Lett. 2016, 18, 6256-6259.

[9] a) D. Zhao, J. Zhang, Z. Xie, J. Am. Chem. Soc. 2015, 137, 9423-9428; b) M. Zhu, C. Zheng, X. Zhang, S.-L. You J. Am. Chem. Soc. 2019, 141, 2636-2644; c) J. Ma, F. Schäfers, C. Daniliuc, K. Bergander, C. A. Strassert, F. Glorius, Angew. Chem. 2020, 132, 9726-9732; Angew. Chem. Int. Ed. 2020, 59, 9639-9645; d) A. B. Rolka, B. Koenig, Org. Lett. 2020, 22, 5035-5040;

[10] a) M. C. DiPoto, R. P. Hughes, J. Wu, J. Am. Chem. Soc. 2015, 137, 14861-14864; b) D.-C. Wang, M.-S. Xie, H.-M. Guo, G.-R. Qu, M.-C. Zhang, S.-L. You, Angew. Chem. 2016, 128, 14317-14321; Angew. Chem. Int. Ed. 2016, 55, 14111-14115; c) D.J. Rivinoja, Y.S. Gee, M.G. Gardiner, J.H. Ryan, C.J.T. Hyland, ACS Catal. 2016, 7, 1053-1056; d) J. Preindl, S. Chakrabarty, J. Waser, Chem. Sci. 2017, 8, 7112-7118; e) M. Laugeois, J. Ling, C. Férard, V. Michelet, V. Ratovelomanana-Vidal, M.R. Vitale, Org. Lett. 2017, 19, 2266-2269; f) J.-Q. Zhao, X.-J. Zhou, Y.-Z. Chen, X.-Y. Xu, X.-M. Zhang, W.-C. Yuan, Adv. Synth. Catal. 2018, 360, 2482-2487; g) Z. Wang, L. Chen, Y. Yao, Z. Liu, J.-M. Gao, X. She, H. Zheng, Org. Lett. 2018, 20, 4439-4443; h) H. Wang, J. Zhang, Y. Tu, J. Zhang, Angew. Chem. 2019, 131, 5476-5480; Angew. Chem. Int. Ed. 2019, 58, 5422-5426; i) J. Ling, D. Mara, B. Roure, M. Laugeois, M.R. Vitale, J. Org. Chem. 2020, 85, 3838-3848; j) M. Manneveau, S. Tanii, F. Gens, J. Legros, I. Chataigner, Org. Biomol. Chem. 2020, 84, 3481-3486.

[11] X. Xu, P.Y. Zavalij, M.P. Doyle, Angew. Chem. 2013, 125, 12896-12900; Angew. Chem. Int. Ed. 2013, 52, $12664-12668$.

[12] a) T. Onnagawa, Y. Shima, T. Yoshimura, J.-I. Matsuo, Tetrahedron Lett. 2016, 57, 3050-3052; b) D.-F. Yue, J.-Q. Zhao, X.-Z. Chen, Y. Zhou, X.-M. Zhang, X.-Y. Xu, W.-C. Yuan, Org. Lett. 2017, 19, 4508-4511; c) Y. He, Z. Liu, D. Wu, Z. Li, K. Robeyns, L. Van Meervelt, E. V. Van der Eycken, Org. Lett., 2019, 21, 4469-4474.

[13] N. De, D. Ko, S. Baek, C. Oh, J. Kim, M.-H. Baik, E.J. Yoo, ACS Catal. 2020, 10, 10905-10913.

[14] a) G. Xu, L. Chen, J. Sun, Org. Lett. 2018, 20, 3408-3412; b) Q. Cheng, J.-H. Xie, Y.-C. Weng, S.-L. You, Angew. Chem. 2019, 131, 5795-5799; Angew. Chem. Int. Ed. 2019, 58, 5739-5743; c) V. Pirovano, E. Brambilla, A. Moretti, S. Rizzato, G. Abbiati, D. Nava, E. Rossi, J. Org. Chem. 2020, $85,3265-3276$

[15] L. Chang, K. Plevová, S. Thorimbert, L. Dechoux, J. Org. Chem. 2017, 82, 5499-5505.

[16] L. He, Y. Yang, X. Liu, G. Liang, C. Li, D. Wang, W. Pan, Synthesis 2020, 52, 459-470.

[17] a) J. Agarwal, O. Bayounes, S. Thorimbert, L. Dechoux, RSC. Adv. 2014, 4, 2772-2775; b) L. Chang, S. Thorimbert, L. Dechoux. Org. Biomol. Chem. 2019,17, 2784-2791; c) Q. Liu, L. Zu, Angew. Chem. 2018, 130, 9649-9653; Angew. Chem. Int. Ed. 2018, 57, 9505-9509.

[18] a) K. Plevová, L. Chang, E. Martin, Q. Llopis, L. Dechoux, S. Thorimbert, Adv. Synth. Catal. 2016, 358, 3293-3297; b) L. Chang, N. Klipfel, L. Dechoux, S. Thorimbert, Green Chem. 2018, 20,1491-1498.

[19] X. Li, H. Yu, Y. Huang, Adv. Synth. Catal. 2017, 359, 1379-1387.

[20] a) M. S. T. Gonçalves, Chem. Rev. 2009, 109, 190-212; b) O. Boutureira, G. J. L. Bernardes, Chem. Rev. 2015, 115, 2174-2195; c) X. Chen and Y.W. Wu, Org. Biomol. Chem. 2016, 14, 5417-5439.

[21] K. Lang, J.W. Chin, ACS Chem. Biol. 2014, 9, 16-20.

[22] T.K. Christopoulos, E.P. Diamandis, Immunoassay, San Diego, Academic Press, 1996, 309-335.

[23] a) C. A. C. Wolfe, D. S. Hage, Anal. Biochem. 1995, 231, 123-130; b) G. T. Hermanson, Bioconjugates Techniques, San Diego, CA, Academic Press, 2008; c) N. Fischer-Durand, M. Salmain, A. Vessières, G. Jaouen, Tetrahedron 2012, 68, 9638-9644. 